Volume and Issues Obtainable at Center for Sustainability Research and Consultancy
Journal of Business and Social Review in Emerging Economies
ISSN: 2519-089X (E): 2519-0326
Volume 6: Issue 2 June 2020
JSRᄃ
Journal homepage: www.publishing.globalcsrc.org/jbsee

\title{
Financial \& Operating Working Capital: Unraveling Obscured Portion of Balance Sheet
}

\author{
Kashif Saeed $^{1}$, Areeba Khan ${ }^{2}$ \\ ${ }^{1} \mathrm{Ph} . \mathrm{D}$ Scholar, Department of Management Sciences, The Islamia University of Bahawalpur, Pakistan, \\ kashifgscc@yahoo.com \\ ${ }^{2}$ Assistant Professor, Department of Management Sciences, The Islamia University of Bahawalpur, \\ Pakistan, \\ areeba.khan@iub.edu.pk
}

\begin{tabular}{l}
\hline ARTICLE DETAILS \\
\hline History \\
Revised format: May 2020 \\
Available Online: June \\
2020 \\
\hline
\end{tabular}

Keywords

Financial working capital, Operating working capital, Trade advanced payments, modified cash conversion cycle ( $m C C C)$

\section{JEL Classification}

P35. P45

\begin{abstract}
Purpose- The purpose of this study is to provide a new obscured aspect of financial working capital in working capital management, and investigate the association between financial and operating working capital with business performance. This paper also examines the interacting effect of net cash flow on this relationship. The current study introduces a modification in cash conversion cycle (CCC) by taking concealed trade advance payments.
\end{abstract}

Design/methodology/approach- This study employs fixed effect regression model, covering a sample of Automobile sector companies, listed at Pakistan Stock Exchange (PSX) for the period of fourteen years from 2005 to 2018. Secondary data is collected from companies' financial annual reports, PSX website, and Balance sheet analysis of State Bank of Pakistan (SBP). The study is explanatory and deductive in nature. Financial working capital (FWC) and new measure of operating working capital (OWC) i.e. modified cash conversion cycle (mCCC) is introduced \& empirically tested with 252 firm-year observations.

Findings- The regression results shows, a convex association between OWC \& FWC, with business performance, in dearth of internal cash. However, after taking interacting effect of internal availability of cash, only FWC relation has become concave. The result also shows that mCCC provides a more realistic view of OWC.

Research limitations/implications- This study has considered, concealed trade prepayments only, further research could include other components in mCCC. Moreover micro, macro factors and status of the economy such as depression or boom may also affect the results of the research. The findings suggest that managers should separately deal operating \& financial working capital. Firms' performance can be enhanced, if Finance Manager Take account internal cash of the firm. In case of deficiency (sufficiency) of it, he should work to decrease (increase) the investment amount in operating working capital (financial working capital). Overall, the results will be helpful to the 
financial experts and business practitioner in analyzing, and utilization of their resources.

Originality/value- This study adds a new dimension in working capital by separating it into operating and financial working capital. The study also offers insights into the new knowledge of extension in CCC, role of concealed advance payments and internal cash flow, for class teachers and business practitioners. It will also describe the new avenues for further research in this field. under a Creative Commons Attribution-NonCommercial-ShareAlike 4.0

Corresponding author's email address: kashifgscc@yahoo.com

Recommended citation: Saeed, K., Khan, A. (2020). Financial \& Operating Working Capital: Unraveling Obscured Portion of Balance Sheet. Journal of Business and Social Review in Emerging Economies, 6 (2), 531-547

\section{Introduction}

\subsection{Background of Study}

Global financial crisis divert the attention of the firms towards the lack of cash in order to fulfill the operational expenses and short term debt obligations. Due to these unexpected changes today's business environment has become more dynamic for the survival of the organization even though the companies are earning profits. Godfred Afrifa (2016) describes the financial management as the management of both short \& long term investment and financing decisions of a firm. Sharma \& Kumar (2011) state that working capital management is an integral segment of financial management and deals with short term financial decisions of a firm.

Working capital relevance on firms' performance has been revisited in latest studies (Aktas et al., 2015; Godfred Afrifa, 2016; Afrifa, Godfred and Tingbani, Ishmael, 2017). Working capital is known as the lifeblood for any economic unit (Aktas et al., 2015). Working capital usually considered as the current building block of firms' balance sheet. Marttonen et al. (2013) classified the WC as operational \& financial capital. Net working capital, simply called working capital, consists of current assets less current liabilities. Knauer and Wöhrmann (2013) state that trade payables, inventories and trade receivables collectively constitutes the OWC. Financial working capital has been defined first time by the Fleuriet et al. (1978), according to them it is the difference of financial assets and financial liabilities. Yritystutkimus (2011) state that trade prepayments are part of the WC. Trade Advance payments are of two types Received advance payments and Paid advance payments. Cash conversion cycle (CCC) is one of the most acceptable measuring technique of WCM. Talonpoika et al. (2014) has presented a modification in the CCC by taking into consideration the received advance payments only.

Figure 1.1: $\quad$ Types and components of Working Capital

Three motives for firm's cash holdings are transactional, speculative and precautionary. Transaction motive for day to day payment of goods and services. Speculative motive for taking 


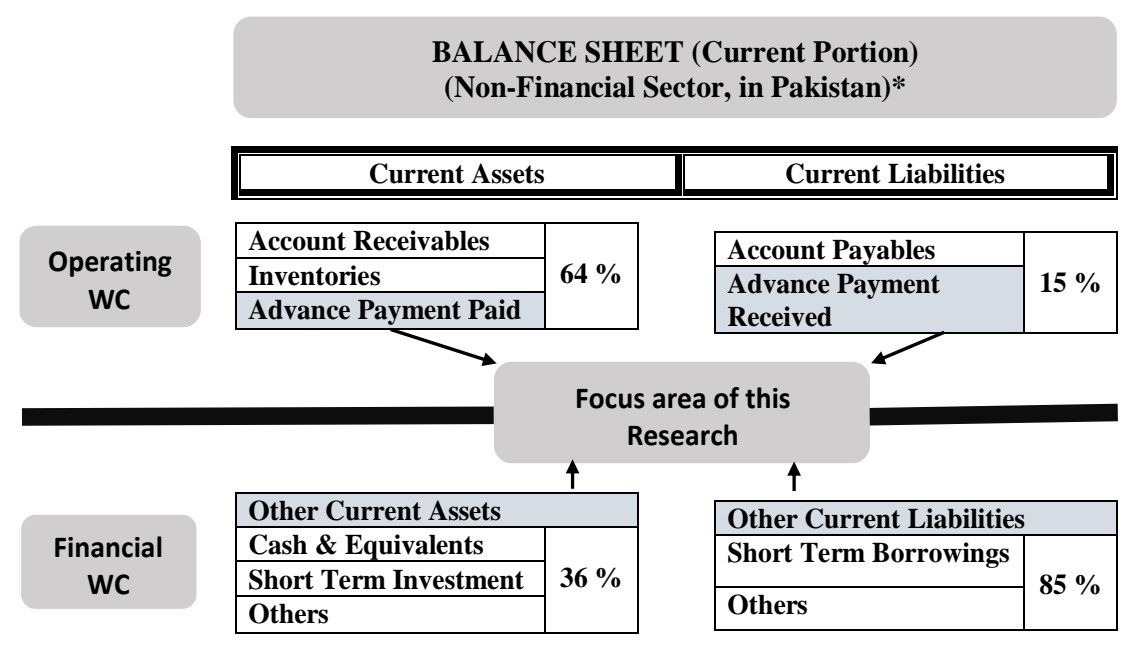

Figure 1.1: Types and components of Working Capital

Three motives for firm's cash holdings are transactional, speculative and precautionary. Transaction motive for day to day payment of goods and services. Speculative motive for taking advantages in any opportunity, while precautionary motive to prevent possible harm in future (Gill and Shah, 2012).

After taking all above considerations, the purpose of this study is to investigate the association between financial and operating working capital with business, in the light of internal cash. Moreover, financial working a new component of working capital and concealed Advanced Payments received and paid are also taken is this study. This research has included some factors as control i.e. dividend payout, financial leverage, size $\&$ age of the firm. This study will contribute new dimensions in the existing academic knowledge.

\subsection{Problem Statement}

In Pakistan, current assets \& current liabilities of non- financial companies are $45 \%$ and $42 \%$ of their total assets respectively (SBP non-financial sector analysis, 2017). It shows that this sector mainly relay on short term source of financing and investment. Presently Pakistani firms utilize 80 to $70 \%$ of their loans, in operational activities. This indicate the general problem that in Pakistan firms' are not properly managing their cash cycle.

Gill \& Biger (2013) believed that inefficiency in WCM have negative effect on firms' profit. Therefore, in today's challenging and dynamic business environment, managers must understand and align WCM accordingly. Finally, a study on WCM (Operating \& Financial) and business performance among nonfinancial sector companies from an emerging market like Pakistan, which contains insufficient evidences and inconsistence in results can be very fruitful empirical work. Which may likely to differ from other developed and developing countries in world wide.

\subsection{Rationale of the Study}

In prior studies, most of the researchers only checked the direct impact of WC on firm performance. But this study has investigated the interacting effect of internal cash on this relationship. The current study introduces a modification in cash conversion cycle (CCC) by unraveling concealed advance payments. This research adds a new dimension in working capital by separating it into operating \& financial working capital. This new obscured aspect is still empirically not tested worldwide which is also a major gap in this area of South Asian emerging market like Pakistan.

\subsection{Objectives of the Study}

The aim of this study is met by the following three objectives: 
- To examine the relationship between FWC and Business Performance.

- To examine the relationship between OWC and Business performance.

- To analyze the interacting effect of internal cash flow on FWC, OWC and Business Performance relationship.

\subsection{Limitations of the Study}

The empirical findings of this research may not be generalizable to all firms, especially for the financial sector because industry, its' formation, its' structure, size and location could also affect firms' performance. Second, due to absence of reliable data, no. of firms and fourteen-year period seems to be short and may be the time constraint of my study research. Finally, during data collection, some of the variables amount for any year, are not found in financial statement which has reduced my sample size.

\section{Literature Review}

In this section, we overview \& review the prior literature on WCM, Business Performance and Net cash flow in order to explore the avenue for future and present research efforts.

\subsection{Concept of Working Capital}

Enqvist et al. (2014) defined WC as current block of firms' balance sheet. WC means the operational capital, it is the amount required by a firm to run its daily routine activities. Aktas et al., (2015) suggests its calculation as "current assets less current liabilities". Kesimili and Gunay (2011) divided the working capital into two types that is Net \& Gross capital. Net working capital shows the amount of difference between current asset and current liabilities. While the Gross working capital shows the amount invested in current assets.

García-Teruel \& Martínez-Solano (2007) described two fundamental approaches i.e. aggressive and conservative approach to manage WC. Conservative policy suggest that a firm must increase the amount in current asset through long term sources. While aggressive policy focus on reducing its amount in current assets (García-Teruel \& Martínez-Solano, 2007).

\subsection{Working Capital Components}

Van Horne \& Wachowicz (2004) describe the main components of WC as inventories, receivables, payables, cash and cash equivalents. According to Aktas et al. (2015) current portion of a firms' balance sheet relate to the main components of WC, which includes Account Payables, Account Receivables and Inventories. Yunos et al. (2015) describe the effective WCM as high rate of profits at low liquidity problem. The main goal of working capital management is to balance the short term financing and investment decisions. Godfred Afrifa (2016) describe that the main goal of a firm is to create value and value creation can be achieved successfully if benefit of tied up in working capital components are more than its cost.

\subsection{Measures of Working Capital Management}

There are several different techniques and versions used in measuring WCM efficiency. The cash conversion cycle is one of them, it is most acceptable and widely used measure. Yazdanfar \& Öhman (2014) describe it as the cyclic time of cash. Some of the well-known versions of CCC are Weighted Cash Conversion Cycle (WCCC), Cash Conversion Efficiency (CCE) and Net Trade Cycle (NTC) (Filbeck \& Krueger, 2005).

Talonpoika (2016) presented the measurement of WCM efficiency by separating it into financial and operational methods. CCC and Cash-to-Cash are common example of operational method. Yritystutkimus (2011) state that trade prepayments are part of the WC. Talonpoika et al. (2014) presented a modification in CCC by taking into consideration the received advance payments only. The results shows more efficiency in measuring OWC through this new measure. Fleuriet et al. (1978) have 
introduced financial working capital in his dynamic working capital model, which is also known as Fleuriet's model. Talonpoika (2016) presented the detail strategies on financial working capital management, his study was based on Marttonen et al. (2013). There is little empirical research on Advance Payments/reverse trade credit. Mateut (2014) in his study concluded that trade prepayments are just like a financing to weaker suppliers and customers. Such kind of financing and its importance is also noticed by Lekkakos and Serrano (2016).

\subsection{Working capital management and Business Performance}

A curvilinear relationship exists between account payable, account receivable, inventory and firm value (Cumbie \& Donnellan, 2017). Kiptoo, I. K., Kariuki, S. \& Kimani, E. M. (2017) concluded that inventory management policy has negative while Payable management practices has positive relationship with Business Performance.

In previous literature there is inconsistency in results several research on working capital management concluded its' negative relation with firms' profitability (Garcia-Teruel \& Martinez-Solano, 2007; Tauringana \& Afrifa, 2013; Banos-Caballero et al., 2013; Sultan, Ahsan \& Wasim, 2017; Cumbie \& Donnellan, 2017). While on the other hand many research have indicated a positive relationship between profitability and working capital (Charitou et al., 2010; Gillet al., 2010; Afeef, 2011; Godfred Afrifa, 2016; Afrifa, Godfred and Tingbani, Ishmael, 2017).

Therefore $\mathrm{H}_{1}$ states:

$\mathrm{H}_{1 \mathrm{~A}} \quad$ There is a significant relationship between Financial Working Capital \& Business Performance.

$\mathrm{H}_{1 \mathrm{~B}} \quad$ There is a significant relationship between Operating Working Capital \& Business Performance.

\section{Conceptual Framework:}

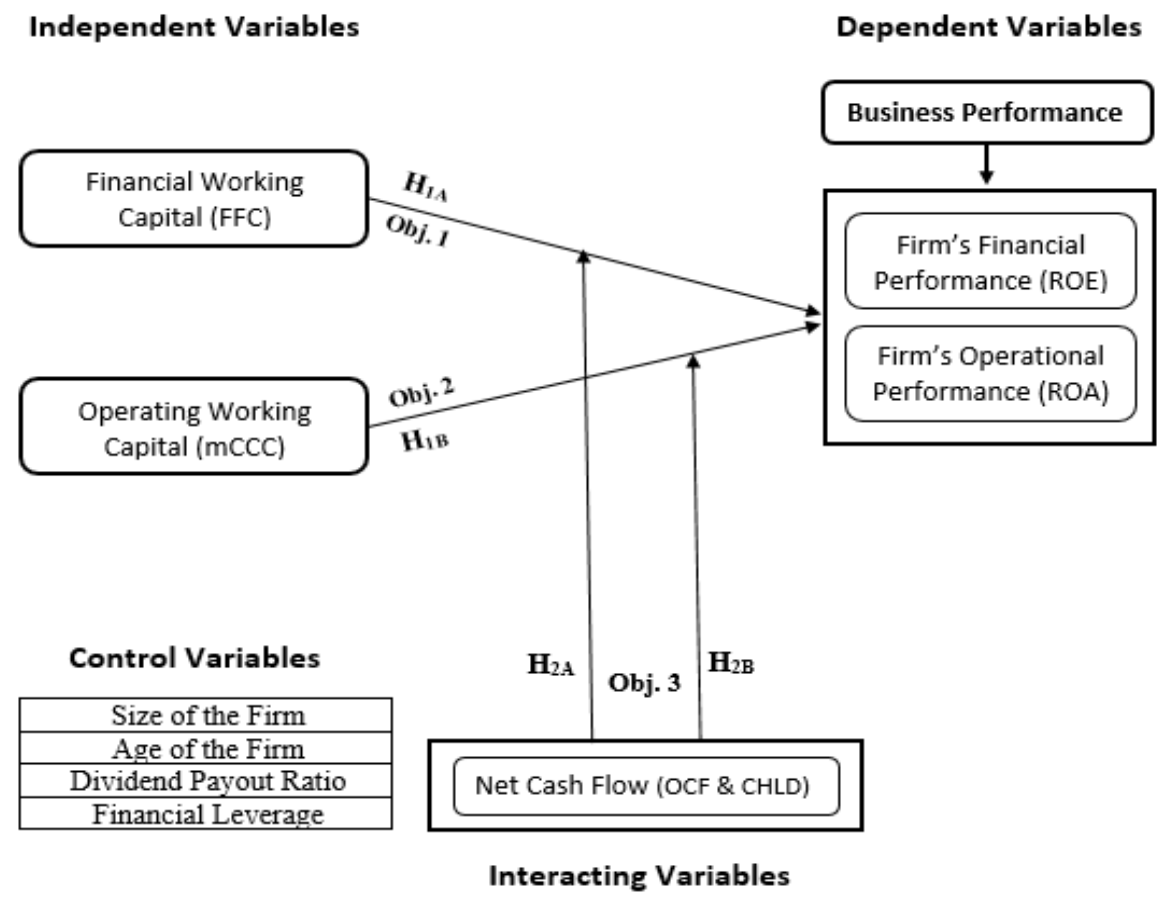

Figure 1.2: Conceptual Framework 


\subsection{Net Cash flow, Working Capital \& Business Performance}

Sultan, Ahsan and Wasim (2017) found that Cash conversion cycle i.e Operating working capital has a negative but significant relationship with firms' profitability. Godfred Afrifa (2016) indicate that in the absence of internal cash, a concave association exists between Net WC and firms' profitability, and it becomes convex if we considered the cash flow.

Firms with limited internal availability of cash flow reduce investment in working capital because for higher investment they needed expensive external financing, which may reduce their performance. Therefore improvement in firm performance linked with amount of investment in WC. Firm can enhance its' performance with investment in WC and availability of internal cash (Afrifa, Godfred and Tingbani, Ishmael, (2017).

Therefore $\mathrm{H}_{2}$ states:

$\mathrm{H}_{2 \mathrm{~A}} \quad$ Internal Net Cash moderate the relationship of FWC \& Business Performance.

$\mathrm{H}_{2 \mathrm{~B}} \quad$ Internal Net Cash moderate the relationship of OWC \& Business Performance.

\section{Research Methodology}

\subsection{Research Design, Sample and Data Collection}

Research design describes the selection process of specific research methods, which are suitable for the current research. This study is Explanatory and deductive in nature. The population of this research is all the 384 non-financial firms listed at Pakistan Stock exchange. As automobile corporate sector is presently highly profitable and advance payments are also seen as a routine practice. So, in order to accomplish the objectives of the research study a sample size is comprises of automobile corporate sector companies listed at Pakistan Stock Exchange are taken for the period of fourteen years 20052018. Substantial missing amounts and anomalies were excluded while covering the sample. Therefore the final sample consists of balanced panel of 18 firms which represents 252 firm-year observations.

\subsection{Estimation and Analysis Techniques}

After fulfilling the Prerequisites of regression such as normality, multicollinearity, and correlation. The following regression equations (models) are used for estimation by using panel data methodology.

$$
\begin{aligned}
& \mathrm{ROA}_{i t}=\beta_{0}+\beta_{1}\left(\mathrm{mCCC}_{\mathrm{it}}\right)+\beta_{2}\left(\mathrm{FFC}_{\mathrm{it}}\right)+\sum_{\mathrm{i}=1} \beta\left(\mathrm{CONTROLS}_{\mathrm{it}}\right)+\mu_{\mathrm{it}} \\
& \mathrm{ROA}_{\mathrm{it}}=\beta_{0}+\beta_{1}\left(\mathrm{mCCC}_{\mathrm{it}} * \mathrm{OCF}_{\mathrm{it}}\right)+\beta_{2}\left(\mathrm{FFC}_{\mathrm{it}} * \mathrm{OCF}_{\mathrm{it}}\right)+\sum_{\mathrm{i}=1}^{4} \beta\left(\mathrm{CONTROLS}_{\mathrm{it}}\right)+\mu_{\mathrm{it}} \\
& \mathrm{ROA}_{\mathrm{it}}=\beta_{0}+\beta_{1}\left(\mathrm{mCCC}_{\mathrm{it}} * \mathrm{CHLD}{ }_{\mathrm{it}}\right)+\beta_{2}\left(\mathrm{FFC}_{\mathrm{it}} * \mathrm{CHLD}_{\mathrm{it}}\right)+\sum_{\mathrm{i}=1}^{4} \beta\left(\mathrm{CONTROLS}_{\mathrm{it}}\right)+\mu_{\mathrm{it}} \quad(\text { eq.3 }) \\
& \mathrm{ROE}_{\mathrm{it}}=\beta_{0}+\beta_{1}\left(\mathrm{mCCC}_{\mathrm{it}}\right)+\beta_{2}\left(\mathrm{FFC}_{\mathrm{it}}\right)+\sum_{\mathrm{i}=1}^{4} \beta\left(\mathrm{CONTROLS}_{\mathrm{it}}\right)+\mu_{\mathrm{it}} \\
& \mathrm{ROE}_{\mathrm{it}}=\beta_{0}+\beta_{1}\left(\mathrm{mCCC}_{\mathrm{it}} * \mathrm{OCF}_{\mathrm{it}}\right)+\beta_{2}\left(\mathrm{FFC}_{\mathrm{it}} * \mathrm{OCF}_{\mathrm{it}}\right)+\sum_{\mathrm{i}=1}^{4} \beta\left(\mathrm{CONTROLS}_{\mathrm{it}}\right)+\mu_{\mathrm{it}} \\
& \mathrm{ROE}_{\mathrm{it}}=\beta_{0}+\beta_{1}\left(\mathrm{mCCC}_{\mathrm{it}} * \mathrm{CHLD}_{\mathrm{it}}\right)+\beta_{2}\left(\mathrm{FFC}_{\mathrm{it}} * \mathrm{CHLD}_{\mathrm{it}}\right)+\sum_{\mathrm{i}=1}^{4} \beta\left(\mathrm{CONTROLS}_{\mathrm{it}}\right)+\mu_{\mathrm{it}}
\end{aligned}
$$


Table No. 1 shows the measurement of all variables, with past studies which use these proxies. In equations (1) to (6), two proxies are used, namely return on equity (ROE) and return on assets (ROA), for the Business Performance (dependent variable) measurement. Modified cash conversion cycle (mCCC) and financial flow cycle (FFC) are used as the two proxies for the independent variables, Operating working capital and financial working capital, respectively. Moreover, mCCC and CCC are pictorially presented in Figure 3.1. Operating cash flow (OCF) and Cash holdings (CHLD) are used for availability of internal finance. Control variables, firm age (AGE), firm size (SIZE), dividend payout ratio (DPOR) and financial leverage (LEV) are included (García-Teruel, P.J. and Martínez-Solano, P. 2007; Deloof, M. 2003; Al Masum, 2014). The subscripts i and t, in above equations 1 to 6, shows the $n t h$ firm and $n t h$ year respectively, while $\mu_{\text {it }}$ is the error term. Fixed effect panel regression model is used after performing the Hausman test. This test accept the alternative hypothesis that the observed heterogeneity is correlated with the regressors and reject the $\mathrm{H}_{0}$ (p-value < 0.05). Random effect model is rejected on the basis of this findings. Moreover, FE model is more effective and coherent method in use. EViews statistical software is used for the analysis.

Table 1. Summary of Variables Calculation

\begin{tabular}{|c|c|c|c|}
\hline Proxy & Abv & Measurements & Author(s) Year \\
\hline \multicolumn{4}{|c|}{ Business Performance (DV) } \\
\hline Return on Assets & ROA & $\begin{array}{l}\text { Earnings before interest and tax } \\
\text { (EBIT)/Total Assets }\end{array}$ & $\begin{array}{l}\text { (Butler, Martin, Perryman, \&Upson, } \\
\text { 2012; Banos- Caballero et al., 2012). }\end{array}$ \\
\hline Return on Equity & $\mathrm{ROE}$ & $\begin{array}{l}\text { Earnings } \text { before interest and tax } \\
\text { (EBIT) /Total Shareholders' } \\
\text { Equity }\end{array}$ & (Abor, 2005; Mwangi et al., 2014). \\
\hline \multicolumn{4}{|c|}{ Financial \& Operating Working Capital (IV) } \\
\hline $\begin{array}{l}\text { Cash Conversion } \\
\text { Cycle }\end{array}$ & $C C C$ & $A A I+A C P-A P P$ & $\begin{array}{l}\text { Richards \& Laughlin (1980), Ding et al. } \\
\text { (2013) }\end{array}$ \\
\hline $\begin{array}{l}\text { modified Cash } \\
\text { Conversion Cycle }\end{array}$ & $m C C C$ & $C C C-A d P R+A d P P$ & Mott (2008), Talonpoika (2014) \\
\hline $\begin{array}{l}\text { Average Age of } \\
\text { Inventory }\end{array}$ & AAI & $\begin{array}{ll}\text { (Average Inventories/Cost } & \text { of } \\
\text { Goods Sold) } \times 365 & \end{array}$ & $\begin{array}{l}\text { Richards \& Laughlin (1980), Ding et al. } \\
\text { (2013) }\end{array}$ \\
\hline $\begin{array}{l}\text { Average Collection } \\
\text { Period }\end{array}$ & $\mathrm{ACP}$ & $\begin{array}{ll}\text { (Average } & \text { Accounts } \\
\text { Receivables/Sales) x } 365\end{array}$ & $\begin{array}{l}\text { Richards \& Laughlin (1980), Ding et al. } \\
\text { (2013) }\end{array}$ \\
\hline $\begin{array}{l}\text { Average Payment } \\
\text { Period }\end{array}$ & APP & $\begin{array}{l}\text { (Ave. Accounts Payables/Cost of } \\
\text { goods sold) x } 365\end{array}$ & $\begin{array}{l}\text { Richards \& Laughlin (1980), Ding et al. } \\
\text { (2013) }\end{array}$ \\
\hline $\begin{array}{l}\text { Advance Payment } \\
\text { Received Period }\end{array}$ & AdPR & $\begin{array}{l}\text { Advance Payment Received / Sales } \\
\text { x } 365\end{array}$ & Mott (2008), Talonpoika (2014) \\
\hline $\begin{array}{l}\text { Advance Payment } \\
\text { Paid Period }\end{array}$ & AdPP & $\begin{array}{l}\text { Advance Payment Paid / Cost of } \\
\text { goods sold x } 365\end{array}$ & Mott (2008), Talonpoika (2014) \\
\hline $\begin{array}{l}\text { Financial Flow } \\
\text { Cycle }\end{array}$ & $F F C$ & $O C A-O C L$ & $\begin{array}{l}\text { Marttonen et al. (2013), Fleuriet et al. } \\
(1978)\end{array}$ \\
\hline $\begin{array}{l}\text { Other } \\
\text { Assets }\end{array}$ & OCA & $\begin{array}{l}\text { (Current Assets - Inventories - A/ } \\
\text { R) / Sales x } 365\end{array}$ & $\begin{array}{l}\text { Marttonen et al. (2013), Fleuriet et al. } \\
(1978)\end{array}$ \\
\hline $\begin{array}{ll}\text { Other } & \text { Current } \\
\text { Liabilities } & \\
\end{array}$ & OCL & $\begin{array}{l}\text { (Current Liabilities - A/ P) / Sales } \\
\text { x } 365\end{array}$ & $\begin{array}{l}\text { (Marttonen et al. (2013), Fleuriet et al. } \\
(1978)\end{array}$ \\
\hline \multicolumn{4}{|c|}{ Availability of Internal Finance (Moderating Variable) } \\
\hline $\begin{array}{l}\text { Operating } \\
\text { Flow }\end{array}$ & $\mathrm{OCF}$ & $\begin{array}{l}\text { Operating income before Depre. \& } \\
\text { Amortization - Interest Exp. \& } \\
\text { Income Tax / Total Assets - } \\
\text { Current Liabilities }\end{array}$ & $\begin{array}{l}\text { Martinez-Sola et al. (2014), Garcia- } \\
\text { Teruel et al. (2014) }\end{array}$ \\
\hline Cash Holdings & $\mathrm{CH}$ & $\begin{array}{l}\text { Cash + Cash Equivalents / Net } \\
\text { Assets(Total Assets }- \text { Current }\end{array}$ & $\begin{array}{l}\text { Martinez-Sola et al. (2014), Garcia- } \\
\text { Teruel et al. (2014) }\end{array}$ \\
\hline
\end{tabular}




\begin{tabular}{|c|c|c|c|}
\hline & & Liabilities) & \\
\hline \multicolumn{4}{|l|}{ Control Variables } \\
\hline Size of the Firm & SIZE & Log of Sales & $\begin{array}{l}\text { García-Teruel, P.J. and Martínez-Solano, } \\
\text { P. (2007); Deloof, M. (2003) }\end{array}$ \\
\hline Age of the Firm & AGE & Log of No. of years & $\begin{array}{l}\text { García-Teruel, P.J. and Martínez-Solano, } \\
\text { P. (2007); Deloof, M. (2003) }\end{array}$ \\
\hline $\begin{array}{l}\text { Dividend Payout } \\
\text { Ratio }\end{array}$ & DPR & $\begin{array}{l}\text { Dividend Per Share / Earning Per } \\
\text { Share }\end{array}$ & $\begin{array}{l}\text { Al Masum, (2014); } \\
\text { Hashemijoo, Ardekani, \& Younesi, } \\
\text { (2012) }\end{array}$ \\
\hline Financial leverage & LEV & $\begin{array}{l}\text { Long term Liabilities as a \% age of } \\
\text { Average total assets }\end{array}$ & $\begin{array}{l}\text { García-Teruel, P.J. and Martínez-Solano, } \\
\text { P. (2007); Deloof, M. (2003) }\end{array}$ \\
\hline Proxy & Abv & Measurements & Author(s) Year \\
\hline \multicolumn{4}{|c|}{ Business Performance (DV) } \\
\hline Return on Assets & ROA & $\begin{array}{l}\text { Earnings before interest and tax } \\
\text { (EBIT)/Total Assets }\end{array}$ & $\begin{array}{l}\text { (Butler, Martin, Perryman, \&Upson, } \\
\text { 2012; Banos- Caballero et al., 2012). }\end{array}$ \\
\hline Return on Equity & ROE & $\begin{array}{l}\text { Earnings } \\
\text { (EBIT) }\end{array}$ & (Abor, 2005; Mwangi et al., 2014). \\
\hline \multicolumn{4}{|c|}{ Financial \& Operating Working Capital (IV) } \\
\hline \begin{tabular}{ll|} 
Cash & Conversion \\
Cycle & \\
\end{tabular} & $C C C$ & $A A I+A C P-A P P$ & $\begin{array}{l}\text { Richards \& Laughlin (1980), Ding et al. } \\
\text { (2013) }\end{array}$ \\
\hline $\begin{array}{l}\text { modified Cash } \\
\text { Conversion Cycle }\end{array}$ & $m C C C$ & $C C C-A d P R+A d P P$ & Mott (2008), Talonpoika (2014) \\
\hline $\begin{array}{l}\text { Average Age of } \\
\text { Inventory }\end{array}$ & AAI & $\begin{array}{ll}\text { (Average Inventories/Cost of } \\
\text { Goods Sold) x } 365\end{array}$ & $\begin{array}{l}\text { Richards \& Laughlin (1980), Ding et al. } \\
\text { (2013) }\end{array}$ \\
\hline $\begin{array}{l}\text { Average Collection } \\
\text { Period }\end{array}$ & $\mathrm{ACP}$ & \begin{tabular}{|l|l|} 
(Average Accounts \\
Receivables/Sales) x 365
\end{tabular} & $\begin{array}{l}\text { Richards \& Laughlin (1980), Ding et al. } \\
\text { (2013) }\end{array}$ \\
\hline \begin{tabular}{ll|} 
Average & Payment \\
Period & \\
\end{tabular} & APP & $\begin{array}{l}\text { (Ave. Accounts Payables/Cost of } \\
\text { goods sold) x } 365\end{array}$ & $\begin{array}{l}\text { Richards \& Laughlin (1980), Ding et al. } \\
\text { (2013) }\end{array}$ \\
\hline
\end{tabular}

\section{modified Cash Conversion Cycle (mCCC)}

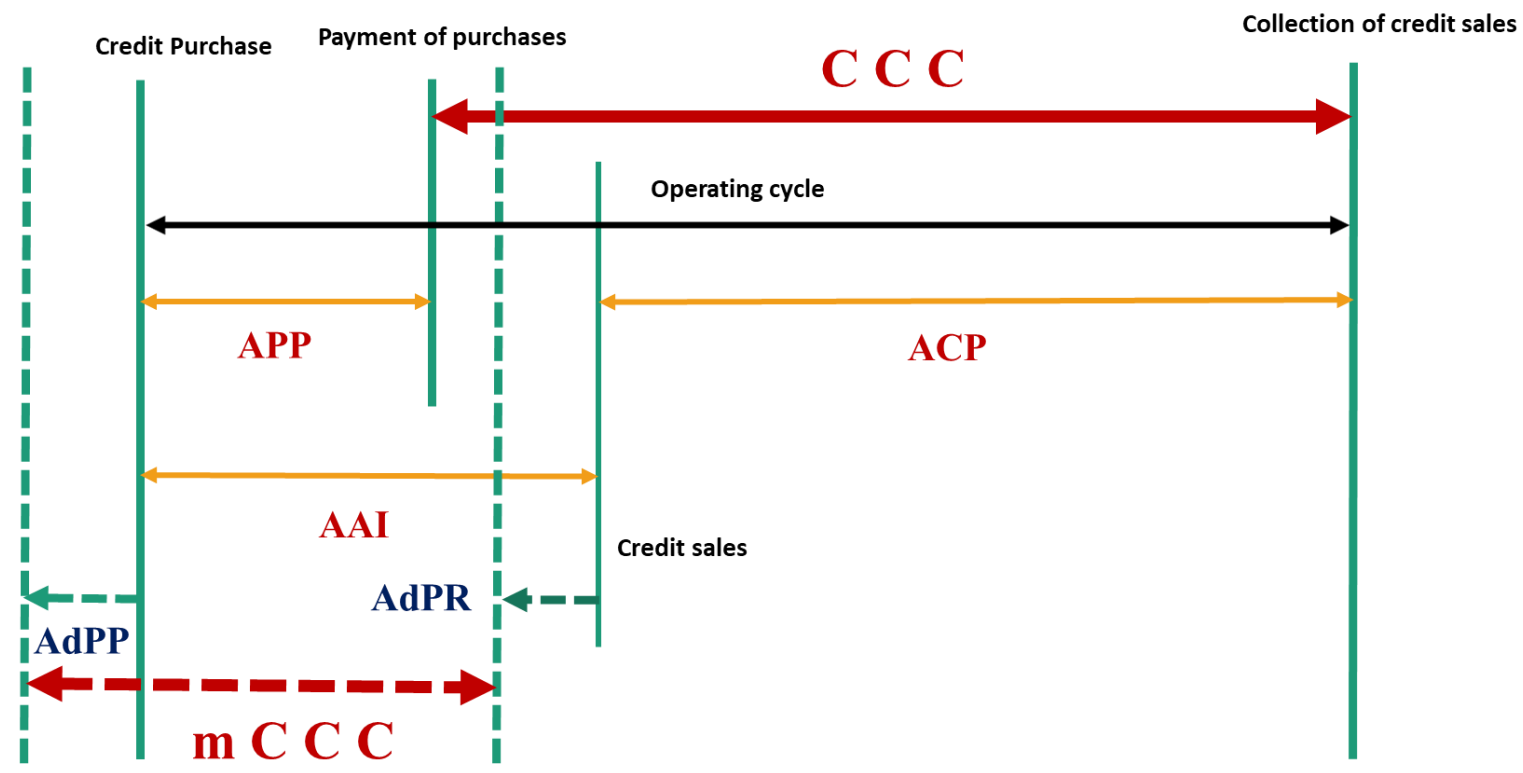

Figure 1.3: Shows the CCC and the Modified Cash Conversion Cycle 


\section{Results and Discussion}

\subsection{Descriptive Analysis}

Table II shows the descriptive statistics of the variables as a whole. Average ROA is $15.11 \%$, while the median is $15.22 \%$. The mean value of ROE is $30.11 \%$ with median of $31.49 \%$, which shows that the automobile sector is one of the most profitably industry in Pakistan. CCC average is 28.29 days, while for the mCCC it is 12.96 days. The median value of CCC is 36.94 days and 30.16 days for mCCC only. The variance between the values of CCC \& mCCC is seem to be large, these values varies from -187 to 186 days and -221 to 230 days respectively. The largest values of mean \& median for CCC can be seen as compare to mCCC. It shows the more WCM efficiency, when the mCCC is observed. If a company received advance before delivery and paid some amount of cash before receiving order then their role is usually remarkable. The mean \& median values of AdPP are $5.7 \& 1.5$ days respectively, which shows it is not very common. While the mean \& median value of AdPR are 7.2 and 21.1 days respectively, indicating advance payment received are common. The average FFC is 17.12 days and median is 18.97 days. The mean \& median DPOR is about $3.699 \& 2.84$ respectively, showing the healthy payout in the industry. The mean and median values are same at 1.49 , showing the maturity of the industry as well. The average value of SIZE is 6.79 and for LEV it is 0.045 , while the median values are $6.86 \& 0.024$, respectively. Finally, the Values of Skewness and Kurtosis are also under the prescribed limits for the Panel Data, which suggest the normality of data.

\section{Table II}

\section{Descriptive statistics}

\begin{tabular}{lccccccccccccc}
\hline \hline & ROA & ROE & CCC & MCCC & FFC & ADPP & ADPR & AGE & SIZE & LEV & DPOR \\
\hline \hline Mean & 0.15110 & 0.30114 & 28.2911 & 12.9610 & 17.1285 & 5.76991 & 21.1000 & 1.49039 & 6.79720 & 0.04536 & 3.69956 \\
Median & 0.15224 & 0.31496 & 36.9440 & 30.1633 & 18.9756 & 1.55700 & 7.24816 & 1.49136 & 6.86365 & 0.02426 & 2.84459 \\
Maximum & 0.85121 & 1.63337 & 186.375 & 230.728 & 625.234 & 80.5599 & 171.144 & 1.81291 & 8.14677 & 0.25283 & 61.8856 \\
Minimum & -1.43074 & -4.75173 & -187.075 & -221.718 & -621.128 & 0.01183 & 0.00000 & 0.84509 & 5.17470 & 0.00000 & -65.5200 \\
Std. Dev. & 0.16779 & 0.44171 & 67.0368 & 83.5720 & 111.937 & 11.5870 & 28.8168 & 0.18229 & 0.64454 & 0.05169 & 7.54413 \\
Skewness & -3.04739 & -6.04947 & -0.54414 & -0.50171 & -0.99906 & 3.44138 & 1.86915 & -0.53512 & -0.14025 & 1.65833 & -0.00294 \\
Kurtosis & 34.0315 & 71.3067 & 3.73298 & 3.18902 & 14.1744 & 16.5834 & 6.75216 & 3.24701 & 2.46388 & 5.88318 & 49.3746 \\
Jarque-Bera & 10501.1 & 50528.1 & 18.0774 & 10.9472 & 1353.03 & 2434.77 & 294.563 & 12.6677 & 3.84409 & 202.787 & 22581.4 \\
Probability & 0.00000 & 0.00000 & 0.00011 & 0.00419 & 0.00000 & 0.00000 & 0.00000 & 0.00177 & 0.14630 & 0.00000 & 0.00000 \\
Sum & 38.0793 & 75.8876 & 7129.37 & 3266.19 & 4316.39 & 1454.01 & 5317.19 & 375.578 & 1712.89 & 11.4316 & 932.291 \\
Sum Sq. Dev. & 7.06705 & 48.9736 & 112798 & 175305 & 3145033 & 33699.2 & 208432 & 8.34112 & 104.273 & 0.67064 & 14285.4 \\
Observations & 252 & 252 & 252 & 252 & 252 & 252 & 252 & 252 & 252 & 252 & 252 \\
\hline \hline
\end{tabular}

\subsection{Correlation Analysis}

Pearson correlation results are shown in Table No. III, it include the coefficients for the variables to test the multicollinearity. These results shows a positive \& significant correlation between ROE \& ROA. The result indicates that ROA \& ROE both have a significant and negative association with mCCC. But on the other hand side ROA \& ROE both have positive significant correlation with FFC. All the control variables such as AGE, SIZE \& DPOR are having positive significant associations with ROA \& ROE, 
except LEV which have a negative significant correlation with them. Finally, the result indicate that independent variables have very low correlation among them. As these correlations are under the suggested limit (i.e. 0.80) by Field (2005), which explain that no multicollinearity exists between them.

\section{Table III}

\section{Correlation}

Matrix

\begin{tabular}{|c|c|c|c|c|c|c|c|c|c|c|}
\hline & ROA & ROE & MCCC & FFC & AGE & SIZE & LEV & DPOR & OCF & CHLD \\
\hline ROA & 1.00000 & & & & & & & & & \\
\hline ROE & 0.69335 & 1.00000 & & & & & & & & \\
\hline MCCC & -0.15052 & -0.20207 & 1.00000 & & & & & & & \\
\hline FFC & 0.16379 & 0.13196 & -0.13719 & 1.00000 & & & & & & \\
\hline AGE & 0.21555 & 0.19767 & 0.13083 & 0.22129 & 1.00000 & & & & & \\
\hline SIZE & 0.32256 & 0.29942 & -0.48283 & 0.25392 & 0.14586 & 1.00000 & & & & \\
\hline LEV & -0.08377 & -0.09392 & 0.12367 & -0.19805 & 0.01628 & -0.13586 & 1.00000 & & & \\
\hline DPOR & 0.32543 & 0.18681 & -0.08508 & 0.26181 & 0.07908 & 0.10151 & -0.09033 & 1.00000 & & \\
\hline OCF & 0.63545 & 0.95226 & -0.18150 & 0.05508 & 0.15569 & 0.28376 & -0.09503 & 0.18297 & 1.00000 & \\
\hline CHLD & 0.14535 & 0.13407 & -0.40581 & 0.35259 & -0.13621 & 0.39646 & -0.26614 & 0.16895 & 0.09359 & 1.00000 \\
\hline
\end{tabular}

4.3. Empirical Results of Regression Analysis

\subsubsection{Effects of Operating \& Financial working capital on Business Performance (ROA)}

The adjusted $\mathrm{R}^{2}$ values show that overall the three models 1 to 3 in Table IV for ROA can explain $53.53 \%, 56.25 \%$ and $43.96 \%$ of all the variability, respectively. F-statistics explain the overall fitness of model, all the 3 models in Table No. IV are significance at the 0.01 level.

The results contained in Model 1 of table IV shows a convex relationship of mCCC \& FFC with ROA, as the coefficients for the mCCC \& FFC are (-0.000675) and (-0.000630) respectively, and both are negatively significance at the 0.01 level. These findings supports $\mathrm{H}_{1}$ hypothesis and indicate that both operating and financial working capital have inverse relationship with business performance (ROA). The result shows that firms' profitability (ROA) and WC relate negatively in the absence of availability of internal cash flow. Therefore, we have examined the possible influence of internal availability of cash flow measured by OCF \& CHLD on this relationship. 


\section{Table IV}

\section{Regression Models}

\begin{tabular}{llll}
\hline \hline Variables & Model 1 (eq.1) & Model 2 (eq.2) & \multicolumn{1}{c}{ Model 3 (eq.3) } \\
\hline \hline mCCC & $-0.000675 * * *(0.0000)$ & & \\
FFC & $-0.000630^{* * *}(0.0000)$ & & \\
mCCC*OCF & & $-0.001139 * * *(0.0042)$ & \\
FFC*OCF & & $0.000542 * * *(0.0000)$ & \\
mCCC $*$ CHLD & & & $-0.000355^{*}(0.1011)$ \\
FFC*CHLD & & & $-0.000517 * *(0.0387)$ \\
AGE & $-0.694127 * * *(0.0000)$ & $-0.485881^{* * *}(0.0001)$ & $-0.538938^{* * *}(0.0003)$ \\
SIZE & $0.335999^{* * *}(0.0000)$ & $0.228078^{* * *}(0.0000)$ & $0.281510^{* * *}(0.0000)$ \\
LEV & $-0.223275(0.2990)$ & $-0.216372(0.3030)$ & $-0.207145(0.3923)$ \\
DPOR & $0.004229 * * *(0.0000)$ & $0.003217 * * *(0.0030)$ & $0.004339 * * *(0.0004)$ \\
C & $-1.084194 * * *(0.0000)$ & $-0.685253 * * *(0.0028)$ & $-0.959718 * * *(0.0002)$ \\
R-squared & 0.577898 & 0.602522 & 0.490981 \\
Adjusted R & 0.535318 & 0.562425 & 0.439632 \\
F-statistic & 13.57190 & 15.02679 & 9.561746 \\
Prob (F-statistic) & 0.000000 & 0.000000 & 0.000000 \\
Observations & 252 & 252 & 252 \\
\hline \hline
\end{tabular}

Notes: This table presents firm fixed effects regression with ROA (Business Performance) as the dependent variable; The above table is showing results of three Models, these models contains results as:

Model 1: without interacting effect of cash flow (OCF \& CHLD)

Model 2 : With interacting effect of Cash flow (OCF)

Model 3 : With interacting effect of Cash flow (CHLD);

The sample consists of 252 firm-years over the period 2005-2018; p-values are in parentheses below coefficients; $* * * * *$ and $*$ represent significance at the $0.01,0.05$ and 0.10 levels, respectively

Model No.2 in Table IV shows the interacting results of cash flow (OCF) with mCCC \& FFC. As the coefficient of $\mathrm{mCCC}^{*} \mathrm{OCF}$ is $(-0.001139)$ and negatively significance at the 0.01 level. Whilst for the FFC ${ }^{*} \mathrm{OCF}$ the coefficient is $(0.000542)$ and positively significance at the 0.01 level. These findings also support $\mathrm{H}_{2 \mathrm{~A}} \& \mathrm{H}_{2 \mathrm{~B}}$ hypothesis.

In terms of interacting effect of cash flow (OCF), the result indicates that a convex association between operating working capital and firm's profitability (ROA) is still held and become stronger. Whilst for the financial working capital this relationship has become concave.

Interacting effect of cash flow (CHLD) with mCCC \& FFC is presented in Model 3 of Table IV. The result shows a convex relation of ROA with $\mathrm{mCCC} \& \mathrm{FFC}$ is still held. As the coefficients of $\mathrm{mCCC}^{*} \mathrm{CHLD} \& \mathrm{FFC} * \mathrm{CHLD}$ are (-0.000355) and (-0.000517), respectively \& also supports the $\mathrm{H}_{2 \mathrm{~A}} \&$ $\mathrm{H}_{2 \mathrm{~B}}$. Whilst both are negatively significance at the 0.10 and 0.05 levels, respectively. The result 
highlighted the influence of internal cash on WC and business performance (ROA) relationship. This result shows the inverse relationship of operating and financial working capital with business performance (ROA) still held, on the interaction of cash flow.

The above results of all three Models shows that in the presence of internal cash, higher level of operating working capital will negatively affect the business performance (ROA), whilst higher level of financial working capital will positively influence business performance (ROA).

\subsubsection{Effects of Operating \& Financial working capital on Business Performance (ROE):}

In current section, the ROE the proxy of financial business performance is used to investigate its' association with OWC and FWC. The adjusted $\mathrm{R}^{2}$ values show that overall these three models 4 to 6 in Table V for ROE can explain $29.23 \%$, 36.98\% and $25.80 \%$ of all the variability, respectively. Fstatistics explain the overall fitness of model, all the 3 models in Table No. IV are significance at the 0.01 level.

The results contained in Table V, Column 1 for Model 4 shows once again a convex relationship of mCCC and FFC with ROE, as the coefficients for the mCCC \& FFC are (-0.001790) and (-0.001343) respectively, both are negatively significance at the 0.01 level. These findings supports $\mathrm{H}_{1}$ hypothesis indicate that both operating and financial working capital have inverse relationship with business performance (ROE). The result shows that firms' performance (ROE) and working capital relate negatively in the absence of availability of internal cash flow. Therefore, we have examined the possible influence of internal availability of cash flow measured by OCF \& CHLD on this relationship.

In Model 5 of Table $\mathrm{V}$ shows the results of the interaction of cash flow (OCF) with mCCC \& FFC. As the coefficients of $\mathrm{mCCC}^{*} \mathrm{OCF}$ and $\mathrm{FFC} * \mathrm{OCF}$ are (-0.005897) and (-0.000304) respectively, and only mCCC*OCF is negatively significance at the 0.01 level \& support $\mathrm{H}_{2 \mathrm{~A}}$. Whilst for the FFC $* \mathrm{OCF}$ it is negatively insignificant and reject the $\mathrm{H}_{2 \mathrm{~B}}$. In terms of interacting effect of cash flow (OCF), the result indicates that only a convex relationship of operating working capital and business performance (ROE) is still held and become stronger.

Interacting effect of cash flow (CHLD) with mCCC \& FFC is presented in Model 6 of Table V. The result shows relationship of ROE with $\mathrm{mCCC} \& \mathrm{FFC}$, both have become concave with the interaction of cash flow. As the coefficients of $\mathrm{mCCC}^{*} \mathrm{CHLD} \&$ FFC*CHLD are (0.001608) and (0.002893) respectively and support the $\mathrm{H}_{2 \mathrm{~A}} \& \mathrm{H}_{2 \mathrm{~B}}$. Whilst both are positively significance at the 0.05 and 0.01 levels, respectively. The result highlighted the influence of internal cash on WC and business performance (ROE) relationship. The result indicate that with the interaction of internal cash this relationship has become opposite.

The results of these three Models 4 to 6 shows that in the presence of internal cash, higher levels of operating and financial working capital will positively influence business performance (ROE). 


\section{Table V}

\section{Regression Models}

\begin{tabular}{llll}
\hline \hline Variables & Model 4 (eq.4) & Model 5 (eq.5) & Model 6 (eq.6) \\
\hline \hline mCCC & $-0.001790^{* * *}(0.0004)$ & & \\
FFC & $-0.001343^{* * *}(0.0001)$ & & \\
mCCC*OCF & & $-0.005897 * * *(0.0000)$ & \\
FFC $*$ OCF & & $-0.000304(0.1667)$ & \\
mCCC*CHLD & & & $0.001608^{* *}(0.0146)$ \\
FFC*CHLD & & & $0.002893 * * *(0.0002)$ \\
AGE & $-1.447541^{* * *}(0.0006)$ & $-1.751601 * * *(0.0000)$ & $-1.513910^{* * *}(0.0007)$ \\
SIZE & $0.684940^{* * *}(0.0000)$ & $0.709441^{* * *}(0.0000)$ & $0.695604 * * *(0.0000)$ \\
LEV & $-1.738415^{* *}(0.0133)$ & $-1.250562^{*}(0.0602)$ & $-1.756568 * *(0.0172)$ \\
DPOR & $0.004354(0.2215)$ & $0.008239^{* *}(0.0158)$ & $0.005532(0.1298)$ \\
C & $-2.088176^{* * *}(0.0057)$ & $-1.908627 * * *(0.0082)$ & $-2.149067 * * *(0.0057)$ \\
R-squared & 0.357184 & 0.427602 & 0.326067 \\
Adjusted R & 0.292339 & 0.369860 & 0.258082 \\
F-statistic & 5.508242 & 7.405392 & 4.796195 \\
Prob (F-statistic) & 0.000000 & 0.000000 & 0.000000 \\
Observations & 252 & 252 & 252 \\
\hline \hline
\end{tabular}

Notes: This table presents firm fixed effects regression with ROE (Business Performance) as the dependent variable; The above table is showing results of three Models, these models contains results as:

Model 4: without interacting effect of cash flow (OCF \& CHLD)

Model 5 : With interacting effect of Cash flow (OCF)

Model 6 : With interacting effect of Cash flow (CHLD);

The sample consists of 252 firm-years over the period 2005-2018; p-values are in parentheses below coefficients; $* * * * *$ and $*$ represent significance at the $0.01,0.05$ and 0.10 levels, respectively

\section{Pictorial presentation of above results findings are as under:}

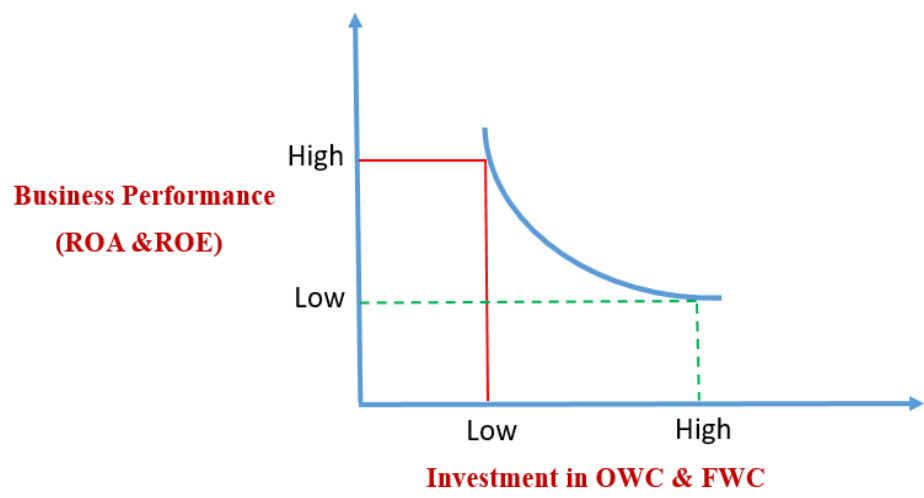

Figure 4.1 In the absence of Internal cash flow (Convex) 


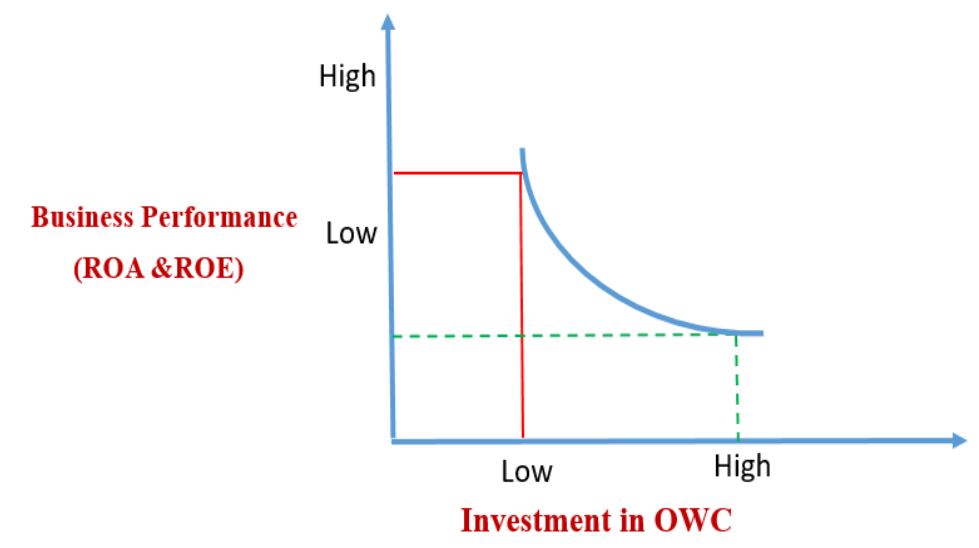

Figure 4.2

Interacting Effect of Internal cash flow* (Convex)
कOCF \& CHLD (ROA)
OCF (ROE)

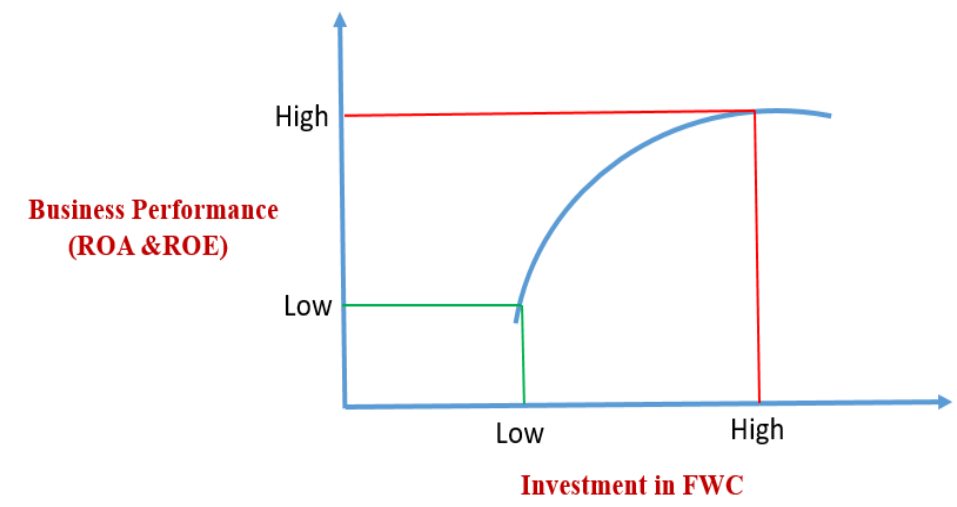

Figure 4.3

$\underset{\text { Interacting Effect of Internal eash flow* (Concave) }}{\text { (ROA) }}$ CHLD (ROE)

\section{Conclusions}

This paper provides empirical evidence and adds a new dimension to working capital, i.e. Financial and Operating working capital, by unraveling obscured portion of balance sheet. Moreover, by revealing concealed advance payments both paid and received, this study has introduced and empirically tested an extension, i.e. Modified cash conversion cycle (mCCC), in CCC. Which is the most acceptable and widely used measuring technique of operating working capital.

Generally CCC is a good measure, but the results shows that mCCC provides a more realistic and efficient view of OWC, especially to those industries which involves advance payments in their dealing. The results show that operating and financial working capital relationship to business performance is convex; however, after considering the interacting effects of internal cash, only the relationship of financial working capital to business performance has become concave. Whilst the operating working capital still hold the convex relationship with business performance.

The finding of the research suggest that managers should separate the working capital into financial and operating working capital, and manage them accordingly. The results highlight the fact that managers should consider internal cash flow and in case of absence of internal cash, firms should strive to reduce the investment in operating and financial working capital. On the other hand, firms with available 
internal cash flow should increase investment in financial working capital only to improve business performance.

Generally the study is important because it will play a very essential and vital role in the academic decisions of efficient working capital. It will be helpful to the financial experts and business practitioner in analyzing, and utilization of their recourses.

The study has offered insights into the new knowledge of financial working capital, new measurement of operating working capital through empirical results of modified cash conversion cycle (mCCC), and the interacting role of Cash flow, and concealed advance payments in the context of this relationship; for business practitioners and class teachers, who deal with working capital and business performance. It also describe the new dimensions to the researchers for future research in this field.

\section{References}

Afeef, M., 2011. Analysing the impact of working capital management on the profitability of SMEs in Pakistan. International Journal of Business and Social Science, 2(22), 173-183.

Afrifa, G. A. (2016). Net working capital, cash flow and performance of UK SMEs. Review of Accounting and Finance, 15, 1, pp.21-44.

Afrifa, Godfred and Tingbani, Ishmael (2017): Working Capital Management, Cash Flow and SMEs' Performance. Forthcoming in: International Journal of Banking Accounting and Finance. 9. 19. 10.1504/IJBAAF.2018.10010466.

Aktas, N., Croci, E., \& Petmezas, D. (2015). Is working-capital management value-enhancing? Evidence from firm performance and investments. Journal of Corporate Finance, 30, 98-113.

Baños-Caballero, S., García-Teruel, P. J. and Martínez-Solano, P., 2013. Working capital management, corporate performance, and financial constraints, Journal of Business Research, Pages 7.

Baños-Caballero, S., García-Teruel, P., \& Martínez-Solano, P. (2012). How does working-capital management affect the profitability of Spanish SMEs? Small Business Economics, 39(2), 517529.

Charitou ,M. S., Elfani, M., and Lois. P., 2010. The effect of Working Capital Management on firms Profitability: Empirical evidence from an Emerging Market. Journal of Business and Economic Research, 8(12), $63-68$.

Cumbie \& Donnellan, (2017), "The Impact of Working Capital Components on Firm Value in US Firms", International Journal of Economics and Finance; Vol. 9, No. 8; 2017.

Deloof, M. (2003), “Does working capital management affect profitability of Belgian firms?” Journal of Business Finance and Accounting, Vol. 30 Nos 3/4, pp. 573-588.

Ding, S., Guariglia, A. and Knight, J. (2013). Investment and financing constraints in China: Does working capital management make a difference?. Journal of Banking \& Finance, 37(5), pp. 1490-1507.

Enqvist, J., Graham, M. \& Nikkinen, J. (2014). The impact of working capital management on firm profitability in different business cycles: Evidence from Finland. Research in International Business and Finance, 32, pp.36-49.

Filbeck, G. \& Krueger, T. (2005). An Analysis of Working Capital Management Results Across Industries. American Journal of Business, 20, 2, pp.11-20.

Fleuriet, M.J., Kehdy, R. and Blanc, G.A. (1978). A Dinâmica financeira das empresas brasileiras. Belo Horizonte: Fundação Dom Cabral. In Portuguese.

García-Teruel, P.J. and Martínez-Solano, P. (2007), "Effects of working capital management on SME 
profitability”, International Journal of Managerial Finance, Vol. 3 No. 2, pp. 164-177.

García-Teruel, P.J., Martínez-Solano, P. and Sánchez-Ballesta, J.P. (2014), "Supplier financing and earnings quality", Journal of Business Finance and Accounting, Vol. 41 Nos 9/10, pp. 11931211. doi: 10.1111/jbfa.12090.

Gill, A., \& Biger, N. (2013). The impact of corporate governance on working capital management efficiency of American manufacturing firms. Managerial Finance, 39, 116-132. doi:10.1108/03074351311293981

Gill, A. and Shah, C. (2012), "Determinants of corporate cash holdings: evidence from Canada", International Journal of Economics and Finance, Vol. 4 No. 1, pp. 70-79.

Godfred Adjapong Afrifa , (2016),"Net working capital, cash flow and performance of UK SMEs", Review of Accounting and Finance, Vol. 15 Iss 1 pp. $21-44$

Hillman, A. J. and T. Dalziel (2003). 'Boards of Directors and Firm Performance: Integrating Agency and Resource Dependence Perspectives', Academy of Management Review, 28, pp. 383-396.

Kim, C.-S., Mauer, D.C. and Sherman, A.E. (1998). The determinants of corporate liquidity: theory and evidence. Journal of Financial and Quantitative Analysis, 33(3), pp.335-359.

Kiptoo, I. K., Kariuki, S. \& Kimani, E. M. (2017). Working capital management practices and financial performance of tea processing firms in Kenya. International Academic Journal of Economics and Finance, 2(3), 92-111

Knauer, T. and Wöhrmann, A. (2013). Working capital management and firm profitability. Journal of Management Control, 24(1), pp. 77-87.

Mateut, S., 2014, Reverse trade credit or default risk? Explaining the use of prepayments by firms, Journal of Corporate Finance 29, 303-326.

Martínez-Sola, C., García-Teruel, P. and Martínez-Solano, P. (2014), "Trade credit and SME profitability", Small Business Economics, Vol. 42 No. 3, pp. 561-577.

Marttonen, S., Monto, S. and Kärri, T. (2013a). Profitable working capital management in industrial maintenance companies. Journal of Quality in Maintenance Engineering, 19(3), pp. 429-446.

Mott, G. 2008. Accountig for Non-Accountants: A Manual for Managers and Students. 7th edition. London: Kogan Page.

Mwangi, L. W., Makau, M. S., and Kosombe, G., 2014. Effects of working capital management on performance of nonfinancial companies listed in NSE, Kenya. European Journal of Business and Management, 6(11), 195-205.

Myers, SC. \& Majluf, NS 1984, 'Corporate financing and investment decisions when firms have information those investors do not have', Journal of Financial Economics, vol. 13, no. 2, pp. 179-218.

Richards, V. D., \& Laughlin, E. J. (1980). A cash conversion cycle approach to liquidity analysis. Financial Management, 9, 32-38.doi:10.2307/3665310

Sharma, AK \& Kumar, S 2011, 'Effect of working capital management on firm profitability empirical evidence from India', Global Business Review, vol. 12, no. 1, pp. 159-173.

Sultan, Ahsan \& Wasim , (2017), "An Empirical Analysis on Efficiency of Working Capital

Management: A case of Pakistan Textile Industry", International Journal of Research Scholars (IJRS) Volume-1, Issue-1, 2017 ISSN 2521-3547, http://www.ijrs.pk

Talonpoika, A., Monto, S., Pirttila, M., \& Karri, T. (2014). Modifying the cash conversion cycle: revealing concealed advance payments. International Journal of Productivity and Performance Management, 63, 341-353. doi:10.1108/IJPPM- 12-2012-0130

Tauringana, V., \& Afrifa, G. A. (2013). The relative importance of working capital management and its components to SMEs' profitability. Journal of Small Business and Enterprise Development, 20, 453-469. doi:10.1108/JSBED-12-2011-0029 
Van Horne, J. C. \& Wachowicz, J. M. (2004). Fundamentals of financial management. Upper saddle River, New York: Prentice Hall International.

Yazdanfar, D. \& Öhman, P. (2014). The impact of cash conversion cycle on firm profitability. International Journal of Managerial Finance, 10, 4, pp.442-452.

Yritystutkimus ry. 2011. Yritystutkimuksen tilinpäätösanalyysi. 9th edition. Helsinki: Gaudeamus.

Yunos, R.M., Nazaruddin, N., Ghapar, F.A., Ahmad, S.A. and Zakaria, N.B. (2015), "Working capital management in Malaysian government-linked companies," Procedia Economics and Finance, Vol. 31, pp. 573-580. 